\title{
A new species of bristletails of the genus Charimacbilis (Microcoryphia: Machilidae) from Crimea
}

\author{
Новый вид щетинохвосток рода Charimachilis \\ (Microcoryphia: Machilidae) из Крыма
}

\author{
Vladimir G. Kaplin \\ Владимир Г. Каплин
}

\begin{abstract}
All-Russian Institute of Plant Protection, St Petersburg, Pushkin 196608 Russia. E-mail: ctenolepisma@mail.ru Всероссийский НИИ защиты растений, Санкт-Петербург, Пушкин 196608, Россия
\end{abstract}

KEY WORDS: Southwestern Palaearctic, Staryi Krym, Machilinae, Charimachilis, taxonomy.

КЛЮЧЕВЫЕ СЛОВА: Юго-Западная Палеарктика, Старый Крым, Machilinae, Charimachilis, таксономия.

ABSTRACT. Charimachilis taurica sp.n. from the vicinity of the city Staryi Krym is described and illustrated. It is compared with parthenogenetic congeners from the Kiev region of Ukraine (C. ukrainensis Stach, 1958), as well as from Rostov (C. rostoviensis Kaplin, 2020) and Belgorod (C. morozovi Kaplin, 2019) regions of the Russian Federation. C. taurica sp.n. can be distinguished from all these species by a larger distance between paired ocelli and the shape of apical palpomere of labial palp. It also differs from C. ukrainensis and $C$. rostoviensis in the structure of compound eyes and urocoxites VIII and IX; and from C. ukrainensis in the by posterior angle of urosternites II-V. C. taurica sp.n. differs from $C$. morozovi in the structure of distal chains of flagellum, number of lateral digging teeth in the distal part of the anterior gonapophyses.

РЕЗЮМЕ. Описан и проиллюстрирован Charimachilis taurica sp.n. из окрестности Старого Крыма. Приведено сравнение нового вида с родственными партеногенетическими видами из Киевской обл. Украины (C. ukrainensis Stach, 1958), а также из Ростовской и Белгородской областей Российской Федерации (соответственно, C. rostoviensis Kaplin, 2020 и C. morozovi Kaplin, 2019). C. taurica sp.n. отличается от них более расставленными парными глазками, формой последнего членика нижнегубного щупика. От C. ukrainensis и C. rostoviensis новый вид отличается также строением глаз и кокситов VIII и IX сегментов брюшка; от $C$. ukrainensis - задним углом стернитов II-V сегментов брюшка; а от $C$. morozovi - строением дистальных цепочек жгутика усиков и развитием боковых копательных зубцов в дистальной части передних створок яйцеклада.

\section{Introduction}

The genus Charimachilis Wygodzinsky, 1939 comprises 14 described species that are distributed in the mountainous landscapes within the subtropical and temperate belts of the Southwestern Palaearctic: between $31^{\circ}$ to $50^{\circ} \mathrm{N}$ (from Israel in the south to the Belgorod region of Russia in the north) and between $11^{\circ}$ and $41^{\circ} \mathrm{E}$ (from Austria in the west to Abkhazia in the east) [Kaplin, 2019]. The position of this genus in the superfamily Machiliodea is not clear, primarly because of the specific features of its ovipositor morphology [Sturm, Bach de Roca, 1993]. Due to the arrangement of scales on the antennae of adults, Mendes [1990] placed it in the subfamily Machilinae. Bach de Roca et al. [2013] considered this genus as incertae sedis group within the Machilidae. Based on the morphological characters of the second and third instar larvae of C. caucasica Kaplin, 1999, as well as on the genital areas of male and female of the genus, Kaplin [2019] suggested that Charimachilis and Turquimachilis Bach de Rocaet et al., 2013 form a group of genera within the Machilinae. Males were found only in populations of $C$. caucasica Kaplin, 1999 and $C$. abchasica Kaplin, 2017 with the largest body sizes (10.6$14 \mathrm{~mm}$ ) from the Great Caucasus. All other species with a body size of 7-10 $\mathrm{mm}$ are parthenogenetic [Kaplin, 1999, 2017, 2019]. Recent collections of bristletails in Crimea (vicinity of the city Staryi Krym) has revealed a new species of this genus; its description is given below.

\section{Materials and methods}

The bristletails were collected by the author into $75 \%$ alcohol. Holotype was dissected and mounted on

How to cite this article: Kaplin V.G. 2021. A new species of bristletails of the genus Charimachilis (Microcoryphia: Machilidae) from Crimea // Russian Entomol. J. Vol.30. No.2. P.123-128. doi: 10.15298/ rusentj.30.2.01 

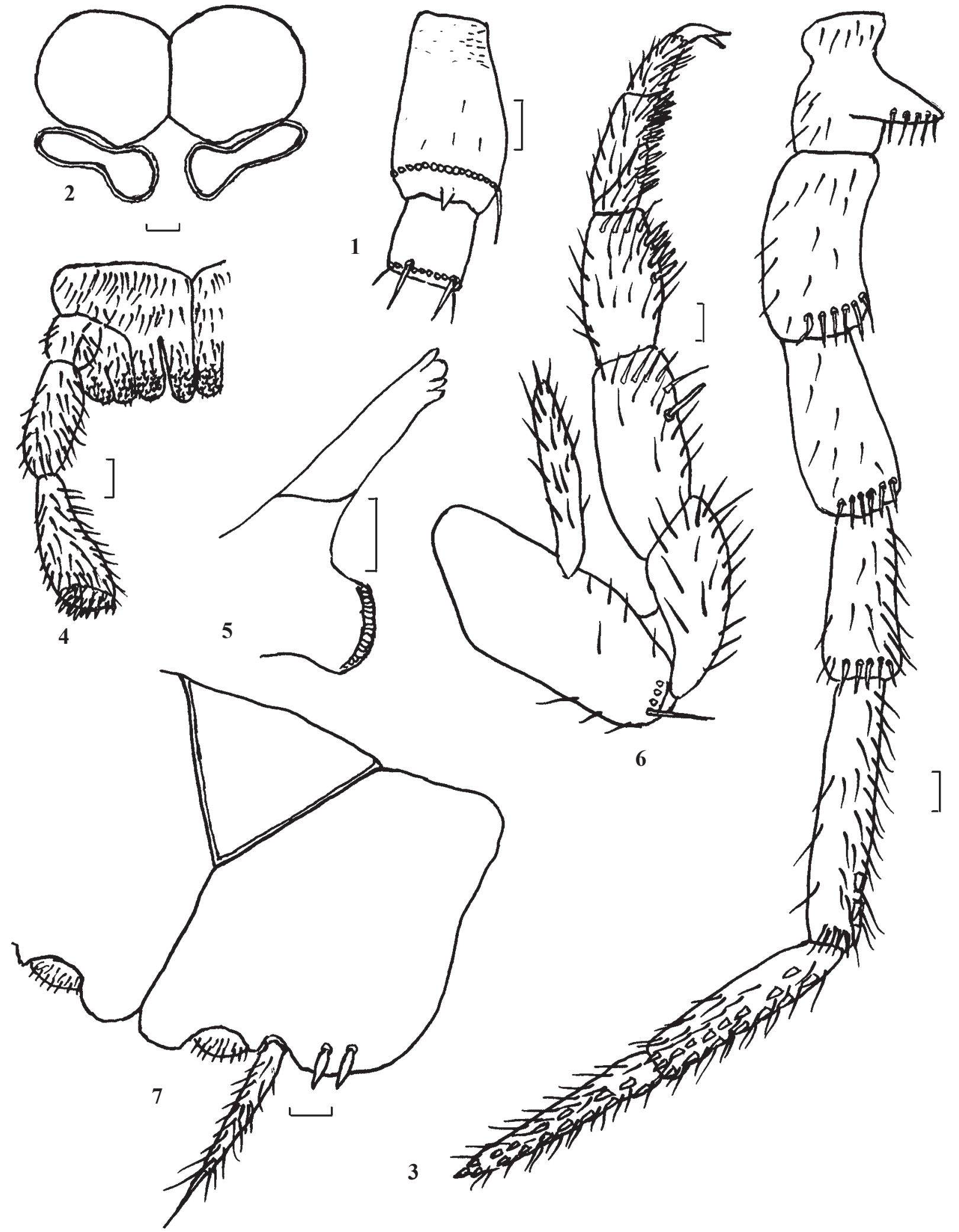

Figs 1-7. Charimachilis taurica sp.n., holotype (female): 1 - scapus and pedicellus of antenna; 2 -anterior part of eyes and paired ocelli; 3 - maxillary palpus; 4 - labial palpus and labium (part); 5 - distal part of mandible; 6 - middle leg; 7 - urosternite and urocoxites VII. Scale bars: $0.1 \mathrm{~mm}$.

Рис. 1-7. Charimachilis taurica sp.n., голотип (самка): 1 - основной членик и стволик усика; 2 - глаза и парные глазки; 3 нижнечелюстной щупик; 4 - нижнегубной щупик и нижняя губа (часть); 5 - дистальная часть верхней челюсти; 6 - средняя нога; 7 - стернит и кокситы VII сегмента брюшка. Масштабные линейки: 0,1 мм. 
glass microscope slides in the Berlese fluid. Figures were made using microscope and a drawing projector. The type of the new species is deposited in the collection of the All-Russian Institute of Plant Protection (VIZR), Russian Academy of Sciences, St. Petersburg.

\section{Results and discussion}

\author{
Order Microcoryphia Verhoeff, 1904 \\ Family Machilidae Grassi, 1888 \\ Subfamily Machilinae
}

Genus Charimachilis Wygodzinsky, 1939

Type species: Praemachilis orientalis Silvestry, 1908

\section{Charimachilis taurica Kaplin, sp.n.}

Figs 1-11.

MATERIAL. Holotype, + Republic of Crimea, vicinity of the city Staryi Krim leg. V. Kaplin 13. IX.2020, mixed forest (Carpinus, Fagus, Fraxinus excelsior, Quercus robur), under stones, $350 \mathrm{~m}$, $45^{\circ} 01^{\prime} \mathrm{N}, 35^{\circ} 05^{\prime} \mathrm{E}$ (VIZR).

DESCRIPTION (holotype). Body length $10.0 \mathrm{~mm}$, width $2.6 \mathrm{~mm}$; total eyes width $0.86 \mathrm{~mm}$, eye length: $0.43 \mathrm{~mm}$; paired ocelli width and length 0.41 and $0.18 \mathrm{~mm}$, respectively; coxal styli length: $0.5-0.6 \mathrm{~mm}$; ovipositor length 1.6 $\mathrm{mm}$. Antennae and cerci are broken. General body color (in alcohol) whitish, with brown and violet hypodermal pigment of weak intensity on head (frons, gena, occiput, lateral parts of clypeus, maxillae. Antenae, maxillary and labial palps, mandibles, legs, cerci, caudal filament without pigment. Scale color on upper and lower surface of body brownish. The chains in the distal part of flagellum divided into 7-9 annuli. Ratio of length to width of scapus of antenna about 1.7 (Fig. 1).

Compound eyes dark brown, slightly lighter towards the contact line (in alcohol). Ratio of length to width of compound eye about 1.0; ratio of contact line to length of eye 0.52 (Fig. 2). Paired ocelli shoe-shaped, dark brown, almost black with narrow white borders. Ratio of distance between inner and outer margins of ocelli to total width of compound eyes, 0.15 and 0.97 , respectively.

Apical palpomere of maxillary palp about as long as previous one (0.98-1.05); ratio of lengths of $5^{\text {th }}$ and $4^{\text {th }}$ palpomeres about 1.44. Dorsal surface of $7^{\text {th }}, 6^{\text {th }}$ and $5^{\text {th }}$ palpomeres of maxillary palp with 15-16, 16 and 3-4 hyaline spines, respectively (Fig. 3). Apical palpomere of labial palp triangularly oval, 2.6-2.7 times longer than wide, with about 18-23 sensorial cones (Fig. 4). Mandibles with four distal teeth (Fig, 5).

Table 1. Length to width ratios of leg segments in female Charimachilis taurica sp.n.

Таблица 1. Отношения длины и ширины основных сегментов ног самки Charimachilis taurica sp.n.

\begin{tabular}{|l|c|c|c}
\hline \multirow{2}{*}{ Segments } & \multicolumn{3}{|c}{ Leg } \\
\cline { 2 - 4 } & fore & middle & hind \\
\hline Tarsus & 4.45 & 3.83 & 4.32 \\
\hline Tibia & 2.20 & 1.98 & 3.01 \\
\hline Femur & 2.01 & 2.28 & 2.41 \\
\hline Coxa & 2.62 & 2.56 & 2.32 \\
\hline
\end{tabular}

Fore and middle tibia and femur widened (Fig. 6). Middle legs shorter than fore and hind legs 1.09 and 1.06 times, respectively. Ratios of length to width of femur, tibia and tarsus as shown in Table 1. Ratio of length of $3^{\text {rd }}$ tarsomere of hind tarsus to total length about 0.34 . Undersurface of femora, tibiae and tarsi with $0-1,2-8$ and $12-18$ hyaline spine-like chaetae, respectively (Table 2). Ratio of length of styli to width of middle and hind coxae about 1.6 and 1.7 , respectively.

Table 2. The number of hyaline spine-like chaetae on the tarsomeres, tibia and femur of female Charimachilis taurica sp.n.

Таблица 2. Количество игловидных щетинок на члениках лапки, голени и бедра у самки Charimachilis taurica sp.n.

\begin{tabular}{|l|l|c|c|c|}
\hline \multicolumn{2}{|c|}{ Segments } & \multicolumn{3}{c|}{ Leg } \\
\cline { 3 - 5 } & 1 ft & 4 & 4 & $6-7$ \\
\hline \multirow{3}{*}{ Tarsomeres } & 2nd & 8 & 8 & 10 \\
\cline { 2 - 5 } & 3rd & 0 & 0 & $0-2$ \\
\hline Tibia & 2 & $4-5$ & $7-8$ \\
\hline Femur & 0 & 1 & 1 \\
\hline
\end{tabular}

Urocoxites I-VII with $1+1$ eversible vesicles. Posterior angle of urosternites II-VI approximately $68-70^{\circ}$, VII about $64^{\circ}$. Length ratios of urosternites and urocoxites II-VI 0.70 0.75 , VII 0.55 . Length ratios of urostyli (not including apical spines) and urocoxites II-VII $0.47-0.50$, VIII 0.74 and IX 0.55 . Length ratios of apical spines and urostyli II-VII 0.40 0.50 , VIII 0.39 , IX 0.30 . Urocoxite VII with well-developed protruding lobes between eversible vesicles. Ratio of length to width of one lobe about 0.58. (Fig. 7). All thoracic tergites and urosternites; urotergites and urocoxites $\mathrm{I}-\mathrm{V}$ without macrochaetae. Urotergites VI with $1+1$, VII with $2+2$, VIII with $3+3$, IX with $2+2$, X with $1+1$; urocoxites VI with 1 +1 , VII with $2+2$, VIII with $2-3+2-3$ and urocoxite IX with 3 outer and 6-7 inner sublateral spines (Figs 8, 9). Undersurface of distal part of urocoxites IX also with numerous medium-sized relatively long chaetae.

Ovipositor sclerotized, thickened, covered by the urocoxites IX, stout, typical of the genus Charimachilis. Gonapophysis VIII with 17 divisions (Fig. 10). Apical divisions with two small lobules and subterminal needle equal in length to two apical divisions taken together. The first apical division also with about 17 sensory short chaetae and 2 thing, longer chaetae. Following two divisions with about 5 small sensory chaetae and 5-7 longer ordinary chaetae. Distal divisions, excepting apical one, with 4-5 lateral digging teeth (Fig 10). Gonapophysis IX with 16 divisions ending with a somewhat curved apical horn at its end and with a subterminal chaeta as long as 3 apical divisions combined (Fig. 11). This division also presents a group of several sensory spines, which are also present in the following 5-6 divisions, but their number decreases towards the base. These divisions also have about 2 chaetae, those of the external part being longer. All divisions of anterior and posterior gonapophyses with chaetae.

Male unknown.

COMPARATIVE REMARKS. Charimachilis taurica sp.n. with digging ovipositor and with $1+1$ eversible vesicles on urocoxites II-V, belongs to the genus Charimachilis 

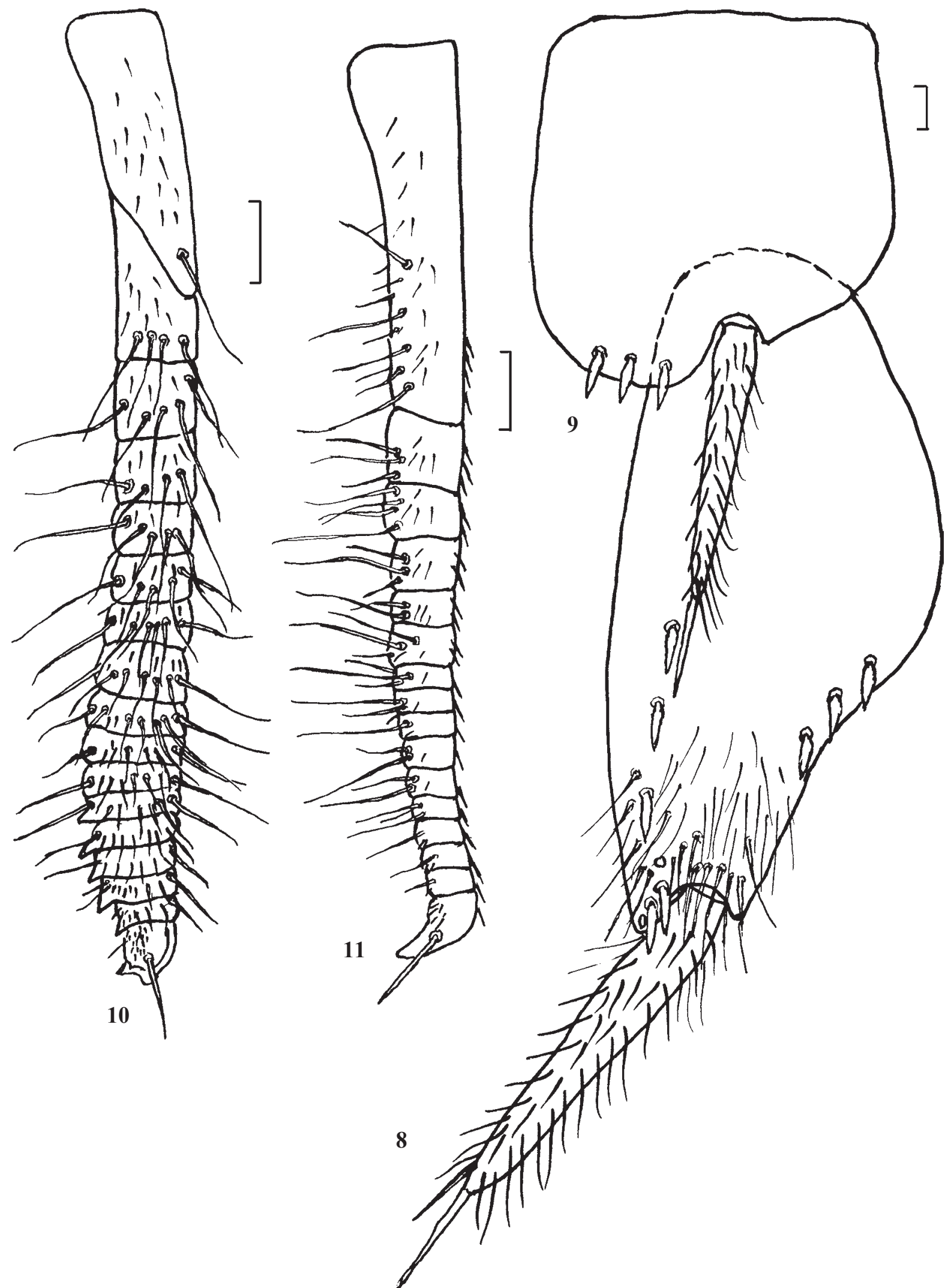

Figs 8-11. Charimachilis taurica sp.n., holotype (female): 8 - urocoxite IX; 9 - urocoxite VIII; 10 - anterior gonapophysis; 11 posterior gonapophysis. Scale bars: $0.1 \mathrm{~mm}$.

Рис. 8-11. Charimachilis taurica sp.n., голотип (самка): 8 - коксит IX сегмента брюшка; 9 - коксит VIII сегмента брюшка; 10 - передняя створка яйцеклада; 11 - задняя створка яйцеклада. Масштабные линейки: 0,1 мм. 
Wygodzinsky including 14 species [Kaplin, 2019; Kaplin, Martynov, 2020]. Charimachilis. taurica sp.n. can be compared to three parthenogenetic congeners known from the Eastern Europe, namely C. ukrainensis Stach, 1958, C. morozovi Kaplin, 2019 and C. rostoviensis Kaplin, 2020. It differs from all these species by the ratio of distance between inner margins of paired ocelli to total width of compound eyes $(0.15$ in $C$. taurica sp.n., $0.08-0.10$ in C. rostoviensis, $0.18-0.20$ in C. morozovi and $0.11-0.13$ in C. ukrainensis) and length to width ratio of apical palpomere of labial palp (2.6-2.7, 2.3-2.4, 2.4-2.5 and 1.9-2.1, respectively). It also differs from C. ukrainensis and C. rostoviensis by the ratio of length to width of compound eye (1.0 in C. taurica sp.n., 0.82 in C. ukrainensis and 0.86 in C. rostoviensis), ratio of length of contact line of eyes to their length $(0.52,0.40,0.33-0.35)$; ratio of length of urostyli to urocoxites VIII $(0.74,0.9,0.95)$ and urocoxites IX $(0.55,0.75,0.46$, respectively). Additionally $C$. taurica and $C$. rostoviensis are characterized by different posterior angle of urosternites II-V $\left(68-70^{\circ}\right.$ in $C$. taurica and $80-86^{\circ}$ in C. rostoviensis). As for C. morozovi, it clearly differs from the new species having more annuli in chains in the distal part of flagellum (7-9 in C. taurica and 10-12 in C. morozovi) and lateral digging teeth on anterior gonapophysis (4-5 in C. taurica and not present in C. morozovi). The main morphological differences between the new species and C. rostoviensis, C. morozovi and C. ukrainensis are summarized in Table 3.
ETYMOLOGY. The new species is named by a suffix that refers to the historical name of Crimea Peninsula (Tauria) where it was collected.

Acknowledgements. I am grateful to Dr. Graeme B. Smith from Australian Museum Research Institute (Sydney, Australia) and to the reviewer for valuable comments, reading and editing the English language text of this paper.

\section{References}

Bach de Roca C., Fanciulli P.-P., Cicconardi F., Molero-Baltanás R., Gaju-Ricart M. 2013. Description of a new genus and a new species of Machilidae (Insecta: Microcoryphia) from Turkey // Soil Organisms. Vol.85. No1. P.31-39.

Kaplin V.G. 1999. New Species of Bristletails of the Families Machilidae and Lepismatidae (Thysanura) from European Russia and Uzbekistan // Entomological Review. Vol.79. No3. P.310-324.

Kaplin V.G. 2017. New species of the bristletail family Machilidae (Insecta, Microcoryphia) from Abkhazia // Entomological Review. Vol.97. No2. P.207-229. https://doi.org/10.1134/ S0013873817020075.

Kaplin V.G. 2019. A Review of the Distribution and Phylogenetic Relationships of Bristletails of the Genus Charimachilis Wygodz. (Archaeognatha, Machilidae) with Descriptions of Larvae of Ch. caucasica Kapl. and of a New Species from Belgorod

Table 3. Main morphological differences between females of C. taurica sp.n., C. rostoviensis, C. morozovi and C. ukrainensis [Stach, 1958; Kaplin, 2019; Kaplin, Martynov, 2020].

Таблица 3. Основные морфологические различия самок C. taurica sp.n., C. rostoviensis, C. morozovi и C. ukrainensis [Stach, 1958; Kaplin, 2019; Kaplin, Martynov, 2020].

\begin{tabular}{|c|c|c|c|c|c|}
\hline \multicolumn{2}{|l|}{ Morphological characters } & $\begin{array}{l}\text { C. taurica } \\
\text { sp. n. }\end{array}$ & $\begin{array}{l}\text { C. } \\
\text { rostoviensis }\end{array}$ & $\begin{array}{l}\text { C. } \\
\text { morozovi }\end{array}$ & $\begin{array}{l}\text { C. } \\
\text { ukrainensis }\end{array}$ \\
\hline \multicolumn{2}{|l|}{ Body length, mm } & 10 & $10-11$ & $7-9$ & 11 \\
\hline \multicolumn{2}{|c|}{ Ratio of length to width of compound eye } & 1.0 & 0.86 & 0.96 & 0.82 \\
\hline \multicolumn{2}{|c|}{ Ratio of length of contact line of eyes to their length } & 0.52 & $0.33-0.35$ & $0.52-0.55$ & 0.40 \\
\hline \multicolumn{2}{|c|}{$\begin{array}{l}\text { Ratio of distance between inner margins of paired ocelli } \\
\text { to total width of compound eyes }\end{array}$} & 0.15 & $0.08-0.10$ & $0.18-0.20$ & $0.11-0.13$ \\
\hline \multicolumn{2}{|c|}{$\begin{array}{l}\text { Ratio of lengths of apical and preceding palpomeres of } \\
\text { maxillary palp }\end{array}$} & $0.98-1.05$ & $1.12-1.14$ & 1.0 & 1.2 \\
\hline \multicolumn{2}{|c|}{$\begin{array}{l}\text { Number of hyaline spines on dorsal surface of the } 6^{\text {th }} \\
\text { palpomere of maxillary palp }\end{array}$} & $3-4$ & $8-9$ & $2-3$ & $?$ \\
\hline \multicolumn{2}{|c|}{$\begin{array}{l}\text { Ratio of length to width of apical palpomere of labial } \\
\text { palp }\end{array}$} & $2.6-2.7$ & $2.3-2.4$ & $2.4-2.5$ & $1.9-2.1$ \\
\hline \multicolumn{2}{|c|}{ Number of annuli in distal chains of flagellum } & $7-9$ & $8-12$ & $10-12$ & $8-9$ \\
\hline \multicolumn{2}{|c|}{ Number of hyaline spine-like chaetae on hind tibia } & $7-8$ & $12-13$ & 7 & 6 \\
\hline \multicolumn{2}{|c|}{ Posterior angle of urosternites II-V, degrees } & $68-70$ & $80-86$ & $70-75$ & $50-70$ \\
\hline \multirow{3}{*}{$\begin{array}{l}\text { Ratio of length of urostyli to urocoxites (not } \\
\text { including apical spines) }\end{array}$} & $\mathrm{II}-\mathrm{V}$ & $0.47-0.50$ & $0.48-0.53$ & $0.45-0.50$ & $0.62-0.68$ \\
\hline & VIII & 0.74 & 0.95 & 0.82 & 0.9 \\
\hline & IX & 0.55 & 0.46 & $0.56-0.57$ & 0.75 \\
\hline \multirow{2}{*}{ Number of sublateral spines on urocoxite IX } & outer & 3 & 1 & $2-3$ & 1 \\
\hline & inner & $6-7$ & 6 & $5-7$ & $6-7$ \\
\hline \multirow{2}{*}{ Number of divisions of gonapophysis } & VIII & 17 & 17 & $16-17$ & 15 \\
\hline & IX & 16 & 15 & $19-20$ & 17 \\
\hline \multicolumn{2}{|c|}{ Number of lateral digging teeth on anterior gonapophysis } & $4-5$ & $4-5$ & 0 & $3-4$ \\
\hline
\end{tabular}


Province // Entmological Review. Vol.99. No1. P.91-115. https://doi.org/10.1134/S0013873819010135.

Kaplin V.G., Martynov V.V. 2020. Three new species of bristletails of the families Meinertellidae and Machilidae (Archaeognatha) from Ukraine and Southern Russia // Acta Entomologica Muse Nationalis Pragae. Vol.60. No.2. P.463-474. https://doi.org/ 10.37520/aemnp.2020.30

Mendes L.F. 1990. An Annotated List of Generic and Specific Names of Machilidae (Microcoryphia, Insecta) with Identifica- tion Keys for the Genera and Geographical Notes // Estudos, Ensaios e Documentos, Instituto de Investigação Cientifica Tropical, Lisboa. Vol.155. P.1-127.

Stach J. 1958. Tmo new species of the genus Charimachilis Wyg. (Thysanura, Machilidae) // Acta Zoologica Cracoviensia. Vol.3. No2. P.49-65.

Sturm H., Bach de Roca C. 1993. On the systematics of the Archaeognatha (Insecta) // Entomologia Generalis. Vol.18. Nos12. P. $55-90$. 